\title{
PENINGKATAN DAN AKTIVITAS HASIL BELAJAR PESERTA DIDIK MENGGUNAKAN MODEL PEMBELAJARAN KOOPERATIF TIPE TAI (TEAM ASSISTED INDIVIDUALIZATION) PADA MATA PELAJARAN KEWIRAUSAHAAN KELAS XI SMK NEGERI 1 SAKRA
}

\author{
Hermany \\ SMK Negeri 1 Sakra \\ Hermanysmk01sakra@gmail.com
}

\begin{abstract}
This study aims to determine (1) increased activity, and (2) student entrepreneurship learning outcomes through the implementation of the cooperative learning model type TAI (Team Assisted Individualization) in class XI Multimedia students of SMK Negeri 1 Sakra. This research is a classroom action research conducted in two cycles with the stages of each cycle including planning, action, observation and evaluation, and reflection. Learning activity data collected by the method of observation and learning outcome data collected through the test method. Data collected was analyzed using quantitative descriptive analysis. The results showed that, (1) the implementation of the TAI type of cooperative learning model can increase the learning activities of students as indicated by the average score of learning activities in the first cycle of 33.5 with the category of active enough and then increased to 39.25 with the active category in the cycle II. (2) Implementation of the TAI type of cooperative learning model can improve student learning outcomes as indicated by an average score of learning outcomes in the first cycle of 77.12 with sufficient categories subsequently increased to 89.35 with very good categories in the second cycle.
\end{abstract}

Keywords: Learning Achievement, Learning Outcomes And TAI Type Of Cooperative Learning Models

\begin{abstract}
Abstrak : Penelitian ini bertujuan untuk mengetahui (1) peningkatan aktivitas, dan (2) hasil belajar Kewirausahaan peserta didik melalui Implementasi model pembelajaran kooperatif tipe TAI (Team Assisted Individualization) pada peserta didik kelas XI Multimedia SMK Negeri 1 Sakra. Penelitian ini merupakan penelitian tindakan kelas yang dilaksanakan dalam dua siklus dengan tahapan-tahapan setiap siklus meliputi perencanaan, tindakan, observasi dan evaluasi, serta refleksi. Data aktivitas belajar dikumpulkan dengan metode observasi dan data hasil belajar dikumpulkan melalui metode tes. Data yang telah dikumpulkan di analisis dengan menggunakan analisis deskriptif kuantitatif. Hasil penelitian menunjukkan bahwa, (1) implementasi model pembelajaran kooperatif tipe TAI dapat meningkatkan aktivitas belajar peserta didik yang ditunjukkan dengan rata-rata skor aktivitas belajar siklus I
\end{abstract}

\footnotetext{
As-Sabiqun : Jurnal Pendidikan Islam Anak Usia Dini

Volume 1, Nomor 2, Oktober 2019; 17-31

https://ejournal.stitpn.ac.id/index.php/assabiqun
} 
sebesar 33,5 dengan kategori cukup aktif selanjutnya meningkat menjadi 39,25 dengan kategori aktif pada siklus II. (2) Implementasi model pembelajaran kooperatif tipe TAI dapat meningkatkan hasil belajar peserta didik yang ditunjukkan dengan rata-rata skor hasil belajar siklus I sebesar 77,12 dengan kategori cukup selanjutnya meningkat menjadi 89,35 dengan kategori sangat baik pada siklus II.

Kata Kunci: Prestasi Belajar, Hasil Belajar Dan Model Pembelajaran Kooperatif Tipe TAI

\section{PENDAHULUAN}

Pendidikan Kewirausahaan merupakan proses secara sistematis dan berkelanjutan baik formal maupun informal dalam rangka membentuk manusia wira usaha. Pendidikan Kewirausahaan ini tidak hanya bertujuan mengubah jiwa atau sikap agar memenuhi kriteria manusia wirausaha, tetapi juga bertujuan untuk dapat meningkatkan ketrampilan dan keahlian tertentu sehingga dapat mendukung seseorang atau suatu masyarakat dalam berwira usaha". "Kewirausahaan adalah gambaran mengenai kemampuan individu dan masyarakat dalam mengembangkan dirinya untuk memanfaatkan potensi yang ada guna menciptakan lapangan pekerjaan dan meningkatkan taraf hidupnya."2

Adapun karakteristik mata pelajaran Kewirausahaan sebagai berikut: 1) Kewirausahaan adalah suatu proses dalam mengerjakan sesuatu yang baru (kreatif) dan berbeda (inovatif) yang bermanfaat dalam memberikan nilai lebih, 2) Kewirausahaan adalah suatu nilai yang diwujudkan dalam perilaku yang dijadikan sumber daya, tenaga penggerak, tujuan, siasat, kiat, proses dan hasil bisnis berorientasi tugas dan hasil, 3) Berani mengambil resiko dan percaya diri, 4) berjiwa kepemimpinan, 5) berorientasi kedepan dan mempunyai pemikiran yang kreatif, 6) mempunyai komitmen yang tinggi dan tanggung jawab terhadap tugasnya ${ }^{3}$.

Pendidikan Kewirausahaan bertujuan untuk membentuk manusia secara utuh (holistik), sebagai insan yang memiliki karakter, pemahaman dan ketrampilan sebagai wirausaha. Pada dasarnya, pendidikan Kewirausahaan dapat diimplementasikan

\footnotetext{
${ }^{1}$ Mario, Naomy. Kewirausahaan. (Jakarta: IN MEDIA. 2013),

${ }^{2}$ Meredith, Geofrey g., et. al... Kewirausahaan : Teori dan Praktek, (Jakarta: PT Binaman Pessindo, Penerjemah : Andre Asparsayogi. 1992)

${ }^{3}$ Suryana, Kewirausahaan, Pedoman Praktis Kiat dan Proses Menuju Sukses, (Bandung, Salemba Empat, 2003)
} 
secara terpadu dengan kegiatan-kegiatan pendidikan di sekolah. Pelaksanaan pendidikan Kewirausahaan dilakukan oleh kepala sekolah, pendidik, tenaga kependidikan (konselor), peserta didik secara bersama-sama sebagai suatu komunitas pendidikan. Pendidikan Kewirausahaan diterapkan kedalam kurikulum dengan cara mengidentifikasi jenis-jenis kegiatan di sekolah yang dapat merealisasikan pendidikan Kewirausahaan dalam bentuk mata pelajara Kewirausahaan dan direalisasikan peserta didik dalam kehidupan sehari-hari ${ }^{4}$.

Model pembelajaran yang sesuai dengan karakteristik pendidikan Kewirausahaan adalah model pembelajaran Team Assisted Individualization (TAI), adapun kelebihan model pembelajaran Team Assisted Individualization menurut Slavin dalam Faturrohman model pembelajaran Team Assisted Individualization (TAI) memiliki enam kelebihan sebagai berikut: 1) Dapat meminimalisasi keterkaitan pendidik dalam pemeriksaan dan pengelolaan rutin, 2) pendidik setidaknya akan menghabiskan separuh dari waktunya untuk mengajar kelompok- kelompok kecil, 3) program tersebut akan sedemikian sederhana sehingga para peserta didik di kelas dapat melakukannya, 4) para peserta didik akan dapat melakukan pengecekan satu sama lain, sekalipun bila peserta didik yang mengecek kemampuannya ada dibawah peserta didik yang dicek dalam rangkaian pengajaran dan prosedur pengecekan akan cukup sederhana dan tidak mengganggu si pengecek, 5) programnya mudah dipelajari baik oleh pendidik maupun peserta didik, tidak mahal, fleksibel, dan tidak membutuhkan pendidik tambahan atau tim pendidik, 6) dengan membuat para peserta didik bekerja dalam kelompok-kelompok kooperatif dan status yang sejajar, program ini akan membangun kondisi untuk terbentuknya sikap-sikap positif terhadap peserta didik-peserta didik mainstream yang memiliki kemampuan kurang dan diantara para peserta didik dari latar belakang rasa tau etnik berbeda, 7) melibatkan peserta didik untuk aktif dalam proses belajar, 8) mereka berdiskusi (discuss), berdebat (debate), atau menyampaikan gagasan, konsep dan keahlian sampai benar-benar memahaminya ${ }^{5}$.

${ }^{4}$ Joko Sutrisno, Pengembangan Pendidikan Berwawasan Kewirausahaan Sejak Usia Dini, (Bandung: IPB. 2003)

${ }^{5}$ Slavin. Kooperative Learning Teori Riset dan Praktik. (Bandung: Nusa Media, 2009.), hlm 
"model pembelajaran Team Assisted Individualization berorientasi pada peserta didik, membangun pengetahuannya sendiri dengan cara melakukan kegiatan diskusi dimana terdapat seorang peserta didik yang lebih mampu berperan sebagai asisten yang bertugas membantu secara individual peserta didik lain yang kurang mampu dalam suatu kelompok",

"Pembelajaran bantuan individual dalam kelompok (Team Assisted Individualization) ini menekankan agar peserta didik bertanggung jawab dalam kegiatan belajar" 7 , Jadi dengan model ini, peserta didik yang mempunyai kemampuan kurang dapat berdiskusi atau bertanya dengan teman kelompoknya yang lebih mampu sehingga peserta didik tersebut memperoleh pengetahuan tambahan, dan peserta didik yang lebih mampu akan memperoleh pemahaman yang lebih tajam karena terlatih pada saat memberikan penjelasan kepada temannya yang kurang mampu. Penerapan model ini juga menghasilkan pemerataan kemampuan pada masingmasing anggota dalam satu kelompok diskusi.

Karakteristik dari pembelajaran Team Assisted Individualization adalah menggunakan konteks saling membantu. pembelajaran bantuan individual dalam kelompok memberikan kesempatan kepada peserta didik untuk melakukan kegiatan tim dengan kinerja tinggi sehingga peserta didik memiliki semangat untuk membangun pengetahuannya sendiri ${ }^{8}$. menjelaskan bahwa kinerja tim yang baik akan menghasilkan suatu pengetahuan baru dan memperoleh penghargaan untuk kelompoknya ${ }^{9}$. Pembelajaran tipe ini dikembangkan diskusi dan komunikasi dengan tujuan agar peserta didik saling berbagi kemampuan, belajar berpikir kritis, menyampaikan pendapat, memberi kesempatan menyalurkan kemampuan, membantu belajar, menilai kemampuan dan peranan diri sendiri maupun teman lain.

Kecocokan dari karakteristik Kewirausahaan dengan model pembelajaran Team Assisted Individualization (TAI) yaitu, karakteristik Kewirausahaan berjiwa kepemimpinan bisa diterapkan dalam model pembelajaran Team Assisted Individualization (TAI) pada saat seorang peserta didik menjadi ketua di dalam

${ }^{6}$ Asma, Nur. 2006. Model Pembelajaran Kooperatif. (Jakarta: Depdiknas, 2006) hlm: 55

${ }^{7}$ Ibid

${ }^{8}$ Suryana, Kewirausahaan, Pedoman Praktis Kiat dan Proses Menuju Sukses, (Bandung, Salemba Empat, 2003.) hlm.

${ }_{9}^{9}$ Slavin. Kooperative Learning Teori Riset dan Praktik. (Bandung: Nusa Media, 2009.), hlm 
kelompoknya. Ketua kelompok dapat mengatur pekerjaan, dan kekompakan dalam kelompoknya. Begitu juga teman- temannya yang sebagai anggota, belajar bekerja sama dengan baik dan kompak agar tugas dapat terselesaikan dengan dan memperoleh hasil yangmaksimal. Apabila sudah terselesaikan dengan baik dan benar, maka ketua kelompok akan memiliki rasa percaya diri pada saat melaporkan hasil diskusinya.

Pembelajaran individual dalam kelompok memiliki tujuan untuk menghasilkan pembelajaran yang bermakna. Pembelajaran yang bermakna membawa peserta didik pada pengalaman belajar yang mengesankan. Pengalaman yang diperoleh peserta didik akan semakin apabila pengetahuan tersebut diperolehnya dari hasil pemahamannya dan penemuannya sendiri. Dalam proses pembelajaran melibatkan peserta didik sepenuhnya. Peranan pendidik hanya sebagai fasilitator dan mediator dalam proses pembelajaran. Pendidik cukup menciptakan kondisi lingkungan belajar yang kondusif bagi peserta didiknya.

Berdasarkan observasi awal di SMK Negeri 1 Sakra, ternyata pembelajaran Kewirausahaan tidak sesuai dengan yang diharapan. Ada beberapa permasalahan yang dihadapi oleh peserta didik dalam proses pembelajaran di kelas diantaranya penyampaian materi dari pendidik kurang disertai dengan contoh sehingga peserta didik sulit memahami materi yang disampaikan dan model pembelajaran yang diterapkan kurang bervariatif sehingga peserta didik menjadi serta keterlibatan peserta didik dalam proses pembelajaran tidak merata, hal ini dikarenakan pendidik kurang memperhatikan peserta didik yang belum memahami materi yang disampaikan sehingga peserta didik tidak dapat mengikuti temannya yang lebih mampu untuk lanjut ke materi berikutnya.

Permasalahan yang dihadapi pendidik dalam proses pembelajaran adalah peserta didik terkadang tidak mendengarkan penjelasan dari pendidik melainkan mengobrol dengan temannya pada saat proses pembelajaran, peserta didik masih takut bertanya dan mengemukakan pendapat, sedangkan dari penulis sendiri mengamati bahwa, tidak memberikan latihan soal dengan merancang lembar kerja peserta didik (LKS) sendiri, melainkan hanya menjawab soal-soal yang ada di buku LKS tanpa memberikan contoh, dalam proses pembelajaran pendidik kurang aktif 
menggunakan model pembelajaran yang sesuai dengan kondisi kelas sehingga pada saat menjelaskan.

Pendidik juga kurang memperhatikan peserta didik yang belum memahami penjelasannya, sedangkan peserta didik yang belum mengerti masih takut bertanya dan mengemukakan pendapat, sehingga peserta didik hanya terpaku pada penjelasan atau penyelesaian masalah diberikan oleh pendidik. Dari perolehan data awal dengan jumlah peserta didik 20 orang dikategorikan sangat aktif sebanyak 1 orang (5\%), peserta didik yang aktif sebanyak 4 orang (20\%), peserta didik yang aktif sebanyak 9 orang (45\%), dan peserta didik yang kurang aktif sebanyak 6 orang $(30 \%)$. Jadi dari data tersebut dapat diketahui bahwa sebagian besar peserta didik kelas XI Multimedia berada pada kategori cukup aktif pada Mata Pelajaran Kewirausahaan, sedangkan untuk data hasil belajar Mata Pelajaran Kewirausahaan diambil dari hasil ulangan harian pertama diperoleh pada saat observasi awal yaitu peserta didik yang tuntas sebanyak 4 orang (20\%), dan peserta didik yang tidak tuntas sebanyak 16 orang (80).

Hasil belajar dikatakan tuntas apabila berada pada persentase hasil belajar 80\%-100\%. Berdasarkan pemaparan diatas satu upaya yang dilakukan adalah dengan pemilihan model pembelajaran yang tepat yaitu dengan pengimplementasian model pembelajaran kooperatif tipe TAI untuk meningkatkan aktivitas dan hasil belajar peserta didik pada mata pelajaran kewirausahaan kelas XI Multimedia SMK Negeri 1 Sakra, tahun Pelajaran 2018/2019.

Penelitian ini bertujuan untuk mengetahui (1) peningkatan aktivitas belajar peserta didik Mata Pelajaran Kewirausahaan kelas X Multimedia SMK Negeri 1 Sakra Tahun Pelajaran 2018/2019 melalui implementasi model pembelajaran kooperatif tipe TAI (Team Assisted Individualization), (2) peningkatan hasil belajar peserta didik Mata Pelajaran kelas XI Multimedia SMK Negeri 1 Sakra Tahun Pelajaran 2018/2019 melalui implementasi model pembelajaran kooperatif tipe TAI (Team Assisted Individuaization). 


\section{METODE}

Penelitian ini dirancang dengan menggunakan Penelitian Tindakan Kelas (PTK) yang dilaksanakan dalam dua siklus guna meningkatkan aktivitas dan hasil belajar peserta didik. Penelitian ini dilaksanakan dalam dua siklus, dan setiap siklusnya terdiri atas empat tahap kegiatan yaitu: (1) perencanaan, (2) tindakan, (3) observasi dan evaluasi, (4) refleksi ${ }^{10}$. Sebelum melakukan penelitian, peneliti mengadakan refleksi awal untuk mengidentifikasi permasalahan- permasalahan yang dialami oleh peserta didik maupun pendidik yang mengampu mata pelajaran Kewirausahaan di kelas XI (Multimedia) SMK Negeri 1 Sakra tahun pelajaran 2018/2019.

Rencana tindakan pada penelitian ini adalah rencana kolaborasi dengan pendidik pelajaran Kewirausahaan, menganalisis masalah yang ditemukan dalam observasi, merencanakan pengimplementasian model kooperatif tipe TAI (Team Assisted Individualization) untuk mengatasi masalah yang muncul, menyiapkan instrumen aktivitas dan hasil belajar peserta didik. Pelaksanaan kegiatan dengan pengimplementasian model pembelajaran kooperatif tipe TAI (Team Assisted Individualizational) akan dilaksanakan dalam beberapa kali yang terdiri dari lima tahapan yaitu, presentasi kelas dan diskusi (tanya jawab), membentuk tim secara heterogen yang beranggotakan 5-6 orang (campuran menurut prestasi, jenis kelamin, suku, ras dan agama yang berbeda) dan pendidik memberikan LKS (Lembar Kerja Peserta didik) untuk dikerjakan oleh masing-masing kelompok dan setelah mengerjakan, peserta didik yang bertugas sebagai ketua kelompok mengumpulkan hasil kerja kelompoknya.

Pendidik memberikan tes akhir setelah pembelajaran berakhir terkait dengan materi dan isi LKS yang dibahas oleh peserta didik dalam kegiatan kelompok kepada seluruh peserta didik, selanjutnya pendidik melaksanakan perhitungan skor dari hasil jawaban LKS setiap kelompok dan mengumumkan skor masing-masing kelompok mulai dari yang tertinggi hingga yang terendah.

Observasi atau pengamatan terhadap peserta didik dilakukan pada saat berlangsungnya kegiatan belajar mengajar di dalam kelas untuk mengamati proses pembelajaran berlangsung. Hal-hal yang diobservasi pada pelaksanaan siklus I dalam

$$
\text { 2002), hlm. }
$$

10 Arikunto, Suharsimi. Prosedur Penelitian Suatu Pendekatan Praktek. (Jakarta: PT. Rineka Cipta. 
penelitian ini adalah melakukan penilaian terhadap aktivitas peserta didik dengan mengisi lembar observasi aktivitas peserta didik, dan kendala- kendala ataupun permasalahan yang ditemukan selama pelaksanaan tindakan siklus I. Observasi yang dilaksanakan dibantu oleh seorang pendidik yang mengampu mata pelajaran Kewirausahaan.

Evaluasi dilaksanakan pada setiap akhir pembelajaran dan akhir siklus, dalam hal ini yang dievaluasi adalah hasil belajar peserta didik dengan memberikan tes obyektif untuk tes akhir pembelajaran, dan tes obyektif dan soal esai pada saat ujian siklus. Refleksi dilakukan pada tiap akhir siklus, dasar refleksi adalah hasil observasi aktivitas dan hasil belajar.

Hasil refleksi siklus pertama ini digunakan sebagai dasar untuk memperbaiki atau menyempurnakan perencanaan dan pelaksanaan pada siklus selanjutnya. Lokasi penelitian ini dilakukan di kelas XI Multimedia SMK Negeri 1 Sakra Lombok Timur NTB. Subjek dari penelitian ini adalah peserta didik kelas XI Multimedia SMK Negeri 1 Sakra yang berjumlah 20 orang peserta didik dan Objek penelitian ini adalah implementasi model pembelajaran kooperatif tipe Team Assisted Individuaization (TAI), aktivitas dan hasil belajar peserta didik.

Jenis dan sumber data (1) jenis data menurut sumbernya yang digunakan dalam penelitian ini adalah data primer, berupa data aktivitas belajar dan data hasil belajar peserta didik serta implementasi model pembelajaran kooperatif tipe Team Assisted Individualization. (2) jenis data menurut sifatnya yang digunakan dalam penelitian ini adalah jenis data kuantitatif, berupa data hasil belajar peserta didik, dan data aktivitas belajar.

Metode pengumpulan data yang digunakan dalam penelitian ini adalah (1) metode tes digunakan untuk mengumpulkan data hasil belajar peserta didik dan tes yang digunakan untuk mengumpulkan data adalah tes akhir tiap siklus, (2) metode observasi digunakan untuk mengumpulkan data aktivitas belajar peserta didik dalam prosespembelajaran. Alat pengumpulan datanya berupa lembar observasi aktivitas 
belajar, (3) metode dokumentasi digunakan untuk mengumpulkan data berupa jumlah peserta didik, foto, dan video/rekaman proses belajar mengajar di dalam kelas ${ }^{11}$.

Teknik analisis data yang digunakan pada penelitian ini adalah analisis deskriptif kuantitatif. Data aktivitas peserta didik diamati dan dicatat dalam lembar observasi, selanjutnya dianalisis secara deskriptif kuantitatif. Kriteria yang digunakan dalam menggolongkan aktivitas belajar peserta didik disusun berdasarkan rata-rata skor aktivitas belajar peserta didik secara klasikal (X), Mean ideal (Mi), dan Standar Deviasi ideal (SDi).

Rumus untuk Mi dan SDi adalah sebagai berikut.

$\mathrm{Mi}=\mathrm{X}($ skor tertinggi ideal + skor terendah ideal) $\mathrm{X}$ (skor tertinggi ideal - skor SDi $=$ terendah ideal ${ }^{12}$.

Keterangan $:$ Mi $=$ Mean ideal (angka rata- rata ideal)

$$
\text { SDi }=\text { Standar Deviasi ideal }
$$

Indikator keberhasilan penelitian tindakan kelas untuk mengetahui hasil belajar peserta didik berpedoman pada Kriteria Ketuntasan Minimal (KKM) yang telah ditetapkan dalam mata pelajaran Kewirausahaan bagi peserta didik kelas XI Multimedia SMK Negeri 1 Sakra yaitu dengan KKM sebesar 80.

\section{HASIL DAN PEMBAHASAN}

Hasil perolehan data aktivitas belajar pada pertemuan pertama menunjukkan bahwa peserta didik yang aktivitas belajarnya berada pada kategori sangat aktif sebanyak 8 orang (40\%), kategori cukup aktif sebanyak 6 orang (30\%), kategori kurang aktif sebanyak 3 orang (15\%), dan kategori sangat kurang aktif sebanyak 1 orang $(5 \%)$. Sedangkan pada pertemuan kedua mengalami penurunan dimana jumlah peserta didik yang aktivitas belajarnya berada pada kategori sangat aktif sebanyak 2 orang (10\%), kategori aktif sebanyak 11 orang (55\%), kategori cukup aktif sebanyak 2 orang $(10 \%)$, kategori kurang aktif sebanyak 3 orang (15\%), dan kategori sangat kurang aktif sebanyak 2orang (10), selengkapnya dapat dilihat pada tabel 1.

11 Arikunto, Suharsimi. Prosedur Penelitian Suatu Pendekatan Praktek. (Jakarta: PT. Rineka Cipta. 2002), hlm. 15

${ }^{12}$ Arikunto, Suharsimi. Prosedur Penelitian Suatu Pendekatan Praktek. (Jakarta: PT. Rineka Cipta. 2002), hlm. 17 
Tabel 1. Aktivitas Belajar Siswa pada Mata Pelajaran Kewirausahaan Siklus I Pada Pertemuan Pertama dan Kedua

\begin{tabular}{lcccc}
\hline \multirow{2}{*}{ Kategori } & \multicolumn{4}{c}{ Aktivitas Belajar Siklus I } \\
\cline { 2 - 5 } & \multicolumn{3}{c}{ Pertemuan I } & \multicolumn{2}{c}{ Pertemuan II } \\
\cline { 2 - 5 } & $\begin{array}{c}\text { Jumlah } \\
\text { Siswa }\end{array}$ & Persentase & Jumlah Siswa & Persentase \\
\hline Sangat Aktif & 2 & $10 \%$ & 2 & $10 \%$ \\
Aktif & 8 & $40 \%$ & 11 & $55 \%$ \\
Cukup Aktif & 6 & $30 \%$ & 2 & $10 \%$ \\
Kurang Aktif & 3 & $15 \%$ & 3 & $15 \%$ \\
Sangat Kurang Aktif & 1 & $5 \%$ & 2 & $10 \%$ \\
$\quad$ Total & 20 & $100 \%$ & 20 & $100 \%$ \\
\hline
\end{tabular}

Berdasarkan hasil tes pada siklus I dengan sub materi hakikat konflik dan pengelolaan konflik yang dilakukan pada setiap akhir siklus, maka diperoleh data hasil belajar peserta didik siklus I dan lebih jelasnya dapat dilihat pada tabel 2 sebagai berikut.

Tabel 2. Hasil Belajar Siswa pada Mata Pelajaran Kewirausahaan Siklus I

\begin{tabular}{lcccc}
\hline No. & Rentangan & Kategori & Jumlah Siswa & Persentase \\
\hline 1 & $85-100$ & Sangan baik & 4 & $20 \%$ \\
2 & $80-84$ & Baik & 10 & $50 \%$ \\
3 & $65-79$ & Cukup & 3 & $15 \%$ \\
4 & $55-64$ & Kurang & 3 & $15 \%$ \\
5 & $0-54 \quad \begin{array}{c}\text { Jumlah } \\
\text { Rata-rata } \\
\text { Kategori }\end{array}$ & & 0 & $\mathbf{1 0 0 \%}$ \\
\multicolumn{2}{r}{} & & $\mathbf{2 0}$ & $\mathbf{7 7 , 1 2}$ \\
Cukup & \\
\hline
\end{tabular}

Berdasarkan analisis tabel 2 orang (20\%), baik sebanyak 10 orang diperoleh nilai tertinggi yang mampu dicapai oleh peserta didik adalah 100 sementara nilai terendah yang diperoleh peserta didik adalah 55 dengan nilai rata-rata peserta didik 77,12 dengan kategori cukup. Jika dibandingkan dengan pedoman konversi hasil belajar peserta didik, maka diperoleh jumlah peserta didik yang berada pada kategori sangat baik sebanyak $4(50 \%)$, cukup sebanyak 3 orang (15\%), kurang sebanyak 3 orang $(15 \%)$, dan sangat kurang tidak ada (0\%). Kriteria Ketuntasan minimal (KKM) mata pelajaran Kewirausahaan di SMK Negeri 1 Sakra adalah 80.

Maka jumlah peserta didik dinyatakan tuntas dapat dilihat pada tabel 3 sebagai berikut

Tabel 3. Sebaran Frekuensi Ketuntasan Hasil Belajar Siswa dalam Pembelajaran Kewirausahaan pada Siklus I

\begin{tabular}{llcc}
\hline \multirow{2}{*}{ No. } & \multirow{2}{*}{ Keterangan } & \multicolumn{2}{c}{ Siklus I } \\
\cline { 2 - 4 } & Tuntas & Frekuensi & Persentase \\
\hline 1 & 14 & $70 \%$ \\
2 & Belum Tuntas & 6 & $30 \%$ \\
& Jumlah Siswa & 20 & $100 \%$ \\
\hline
\end{tabular}


Berdasarkan tabel 3 di atas dapat diketahui bahwa jumlah peserta didik yang telah tuntas dalam mata pelajaran Kewirausahaan sebanyak 14 orang (70\%), sedangkan jumlah peserta didik yang belum tuntas sebanyak 6 orang (30\%). Hasil perolehan data aktivitas belajar pada siklus II pertemuan pertama menunjukkan bahwa peserta didik yang aktivitas belajarnya berada pada kategori sangat aktif sebanyak 4 orang (20\%), kategori aktif sebanyak 11 orang (55\%), kategori cukupaktif sebanyak 4 (20\%), kategori kurang aktif tidak ada (0\%), kategori sangat kurang aktif sebanyak 1 orang (5\%). Sedangkan pada pertemuan kedua menunjukkan peserta didik yang aktivitas belajarnya berada pada kategori sangat aktif sebanyak 6 orang (30\%), kategori aktif sebanyak 11 orang (55\%), kategori cukup aktif sebanyak 3 $(15 \%)$, kategori kurang aktif tidak ada $(0 \%)$, kategori sangat kurang aktif tidak ada $(0 \%)$. Selengkapnya dapat dilihat pada tabel 4 sebagai berikut

Tabel 4. Data Aktivitas Belajar Siswa pada Mata Pelajaran Kewirausahaan Siklus II

\begin{tabular}{lcccc}
\hline \multirow{2}{*}{ Kategori } & \multicolumn{4}{c}{ Aktivitas Belajar Siklus II } \\
\cline { 2 - 5 } & \multicolumn{2}{c}{ Pertemuan I } & \multicolumn{2}{c}{ Pertemuan II } \\
\cline { 2 - 6 } & Jumlah Siswa & Persentase & Jumlah Siswa & Persentase \\
\hline Sangat Aktif & 4 & $20 \%$ & 6 & $30 \%$ \\
Aktif & 11 & $55 \%$ & 11 & $55 \%$ \\
Cukup Aktif & 4 & $20 \%$ & 3 & $15 \%$ \\
Kurang Aktif & 0 & $0 \%$ & 0 & $0 \%$ \\
Sangat Kurang & 1 & $5 \%$ & 0 & $0 \%$ \\
Aktif & & & & $100 \%$ \\
\multicolumn{1}{c}{ Total } & 20 & $100 \%$ & 20 & \\
\hline
\end{tabular}

Berdasarkan hasil tes pada siklus II dengan sub materi hakikat konflik dan pengelolaan konflik yang dilakukan pada setiap akhir siklus, maka diperoleh data hasil belajar peserta didik siklus II dan lebih jelasnya dapat dilihat pada tabel 5 sebagai berikut.

\section{Tabel 5}

\begin{tabular}{ccccc}
\hline No. & Rentangan & Kategori & Jumlah Siswa & Persentase \\
\hline 1 & $85-100$ & Sangan baik & 12 & $60 \%$ \\
2 & $80-84$ & Baik & 6 & $30 \%$ \\
3 & $65-79$ & Cukup & 2 & $10 \%$ \\
4 & $55-64$ & Kurang & 0 & $0 \%$ \\
5 & $0-54$ & Sangat kurang & 0 & $0 \%$ \\
\multicolumn{2}{c}{$\begin{array}{c}\text { Jumlah } \\
\text { Rata-rata }\end{array}$} & $\mathbf{2 0}$ & $\mathbf{1 0 0} \%$ \\
\multicolumn{2}{c}{ Kategori } & \multicolumn{3}{c}{ Sangat Baik } \\
\hline
\end{tabular}


Berdasarkan analisis tabel 5 diperoleh nilai tertinggi yang mampu dicapai oleh peserta didik adalah 97,5 sementara nilai terendah yang diperoleh peserta didik adalah 71 rata-rata peserta didik 89,35 dengan kategori cukup. Jika dibandingkan dengan pedoman konversi hasil belajar peserta didik, maka diperoleh jumlah peserta didik yang berada pada kategori sangat baik sebanyak 12 orang (60\%), baik sebanyak 6 orang (30\%), cukup sebanyak 2 orang (10\%), kurang tidak ada (0\%), dan sangat kurang tidak ada (0\%). Kriteria Ketuntasan minimal (KKM) mata pelajaran Kewirausahaan di SMK Negeri 1 Sakra adalah 80.

Maka jumlah peserta didik yang dinyatakan tuntas dapat dilihat pada tabel 6 sebagai berikut

Tabel 6. Sebaran Frekuensi Ketuntasan Hasil Belajar Siswa dalam Pembelajaran Kewirausahaan pada Siklus II

\begin{tabular}{llcc}
\hline \multirow{2}{*}{ No. } & Keterangan & \multicolumn{2}{c}{ Siklus II } \\
\cline { 3 - 4 } & Tuntas & Frekuensi & Persentase \\
\hline 1 & 18 & $90 \%$ \\
2 & Belum Tuntas & 2 & $10 \%$ \\
& Jumlah Siswa & 20 & $100 \%$ \\
\hline
\end{tabular}

Berdasarkan tabel 6 di atas dapat diketahui bahwa jumlah peserta didik yang telah tuntas dalam mata pelajaran Kewirausahaan sebanyak 18 orang (90\%), sedangkan jumlah peserta didik yang belum tuntas sebanyak 2 orang $(10 \%)$. Dari data tersebut, penelitian ini sudah memenuhi standar ketuntasan klasikal yang ditetapkan SMK N 1 Sukasada untuk mata pelajaran Kewirausahaan yaitu dengan KKM 80. Dengan diterapkannya model pembelajaran TAI peserta didik dapat memahami materi pelajaran dengan mudah, selain itu peserta didik mempunyai tanggung jawab penuh terhadap tugas yang diberikan pada pendidik sehingga peserta didik dapat mengembangkan potensinya secara optimal.

\section{PEMBAHASAN}

Berdasarkan hasil penelitian yang telah dilaksanakan selama dua siklus penelitian ini menunjukkan terjadinya peningkatan aktivitas dan hasil belajar Kewirausahaan setelah pengimplementasian model pembelajaran kooperatif tipe TAI. Pada pertemuan pertama rata-rata aktivitas belajar peserta didik sebesar 33,8\% dan pada pertemuan kedua mengalami penurunan sebesar $0,6 \%$ menjadi 33,2\%, dengan demikian dapat disimpulkan bahwa rata-rata aktivitas belajar peserta didik 
pada siklus I adalah 33,5. Bila dikonversikan ke dalam penggolongan aktivitas belajar peserta didik berada pada rentang 29,25 - <35,75 atau berada dalam kategori cukup aktif. Hal ini menunjukkan bahwa aktivitas belajar peserta didik masih rendah sehingga perlu adanya perbaikan agar aktivitas belajar peserta didik meningkat.

Pada siklus II pertemuan pertama rata-rata aktivitas belajar peserta didik sebesar 37,85\% dan pada pertemuan kedua mengalami peningkatan sebesar 2,8\% menjadi 40,65\%, dengan demikian, dapat disimpulkn bahwa rata-rata aktivitas belajar peserta didik pada siklus II adalah 39,25. Bila dikonversikan ke dalam penggolongan aktivitas belajar peserta didik berada pada rentangan 35,8 $-<42,5$ atau berada dalam kategori aktif. Berdasarkan hasil analisisata tersebut, dapat diketahui bahwa terjadi peningkatan aktivitas belajar peserta didik pada siklus II.

Berdasarkan hasil tersebut dapat dibandingkan antara siklus I dengan siklus II yaitu skor aktivitas belajar peserta didik mengalami peningkatan sebesar 5,75\%. Walaupun dari siklus I ke siklus II aktivitas belajar peserta didik mengalami peningkatan namun pada proses pembelajaran siklus I masih terdapat kendala dalam proses pembelajaran. Kendala tersebut kemudian ditindaklanjuti dengan mencari alternatif pemecahan untuk melaksanakan siklus yang ke II. Pada siklus II aktivitas belajar peserta didik sudah mengalami peningkatan dimana peserta didik sudah berani mengajukan pertanyaan kepada teman atau pendidik apabila ada hal yang belum mereka pahami, dengan percaya diri peserta didik tampil di depan kelas sebagai ketua kelompok yang menyajikan materi dan membantu anggotanya di dalam menjawab pertanyaan dari teman yang lain pada saat melaksanakan presentasi serta melakukan pembagian tugas kepada anggota kelompoknya agar semua anggota mengerjakan tugas.

Pemberian poin atau penghargaan mampu meningkatkan aktivitas belajar peserta didik hal ini dikarenakan dengan pemberian poin atau penghargaan membuat peserta didik lebih bersemangat dalam mengikuti pembelajaran, semua peserta didik bekerjasama pada saat berdiskusi kelompok sehingga alokasi waktu pelaksanaan diskusi dapat berjalan dengan efektif, sebagian besar peserta didik sudah termotivasi untuk bertanya kepada Penelitian ini sejalan dengan kelompok lain pada saat presentasi sehingga proses pembelajaran lebih aktif. Model pembelajaran kooperatif 
tipe TAI juga dapat meningkatkan hasil belajar peserta didik pada mata pelajaran Kewirausahaan.

Peningkatan hasil belajar peserta didik dapat dilihat dari adanya peningkatan rata-rata kelas sebesar 12,23 dari 77,12 dengan kategori cukup pada siklus I menjadi 89,35 pada siklus II dengan kategori sangat baik. Ketuntasan belajar klasikal pada siklus I sebanyak 14 orang (70\%) yang mengalami peningkatan pada siklus II menjadi 18 orang $(90 \%)$ peserta didik yang tuntas. Peningkatan hasil belajar tersebut juga dicapai melalui variasi kegiatan pembelajaran seperti pendidik membimbing peserta didik yang pada awalnya mengalami kesulitan dalam memahami materi dan pada pertemuan selanjutnya peserta didik mulai termotivasi untuk belajar, memberikan pernyataan arahan untuk menumbuhkan pemahaman peserta didik terhadap materi dan memberikan penghargaan sebagai timbal balik dari kegiatan peserta didik serta hasil yang dicapai peserta didik akan membuat peserta didik lebih bersemangat untuk belajar.

Peningkatan aktivitas belajar dan hasil belajar peserta didik sejalan dengan “pembelajaran kooperatif merupakan model pembelajaran yang dapat meningkatkan kinerja peserta didik dalam tugas-tugas akademik, unggul dalam membantu peserta didik memahami konsep- konsep yang sulit, dan membantu peserta didik

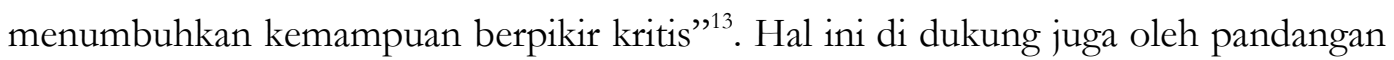
Oemar Hamalik yang menyatakan bahwa untuk mencapai hasil belajar yang optimal dalam pembelajaran perlu ditekankan adanya aktivitas peserta didik baik secara fisik, mental, intelektual, maupun emosional. Berdasarkan hasil tindakan pada siklus I dan siklus II dapat dikatakan bahwa pengimplementasian model pembelajaran kooperatif tipe Team Assisted Individualization (TAI) dapat meningkatkan aktivitas dan hasil belajar peserta didik kelas XI (Multimedia) SMK Negeri 1 Sakra pada mata pelajaran Kewirausahaan tahun Pelajaran 2018/2019.

Jadi, dapat disimpulkan bahwa pengimplementasian model pembelajaran kooperatif tipe TAI (Team Assisted Individualization) dapat meningkatkan aktivitas dan hasil belajar peserta didik kelas XI (Multimedia) 2 SMK Negeri 1 Sakra pada mata pelajaran Kewirausahaan tahun ajaran 2018/2019.

${ }^{13}$ Daryanto. Penelitian Tindakan Kelas. (Jakarta: PT. Prestasi Pustakaraya. 2012), hlm: 59 


\section{KESIMPULAN}

Berdasarkan hasil analisis dan pembahasan pada bab IV, maka dapat ditarik kesimpulan sebagai berikut.

1. Implementasi model pembelajaran kooperatif tipe TAI (Team Assisted Individualization) dapat meningkatkan aktivitas belajar peserta didik kelas XI MM (Multimedia) SMK Negeri 1 Sakra tahun pelajaran 2018/2019. Hal ini dapat dilihat dari rata-rata aktivitas belajar peserta didik secara klasikal pada siklus I sebesar 33,5 yang berada pada kategori cukup aktif dan mengalami peningkatan sebesar 5,75\% pada siklus II menjadi 39,25 yang berada pada kategori aktif.

2. Implementasi model pembelajaran kooperatif tipe TAI (Team Assisted Individualization) dapat meningkatkan hasil belajar peserta didik kelas X MM (Multimedia) SMK Negeri 1 Sakra tahun pelajaran 2018/2019. Hal ini dapat dilihat dari rata-rata hasil belajar peserta didik secara klasikal pada siklus I sebesar 77,12 dengan kategori cukup, jumlah peserta didik yang tuntas sebanyak 14 orang (70\%), dan jumlah peserta didik yang belum tuntas sebanyak 6 orang (30\%). Pada siklus II rata-rata hasil belajar peserta didik secara klasikal mengalami peningkatan menjadi 89,35 dengan kategori sangan baik, jumlah peserta didik yang tuntas sebanyak 18 orang (90\%), dan jumlah peserta didik yang belum tuntas sebanyak 2 orang $(10 \%)$.

\section{DAFTAR PUSTAKA}

Arikunto, Suharsimi. 2002. Prosedur Penelitian Suatu Pendekatan Praktek. Jakarta: PT. Rineka Cipta.

Asma, Nur. 2006. Model Pembelajaran Kooperatif. Jakarta: Depdiknas

Daryanto. 2012. Penelitian Tindakan Kelas. Jakarta: PT. Prestasi Pustakaraya.

Hamalik, O. 2008. Proses Belajar Mengajar. Jakarta: PT Bumi Aksara.

Prianto, Agus. 2008. Ekonomi Mikro. Setara Press. Malang

Meredith, Geofrey g., et. al.. 1992. Kewirausahaan : Teori dan Praktek, Jakarta: PT Binaman Pessindo, Penerjemah : Andre Asparsayogi.

Slavin. 2009. Kooperative Learning Teori Riset dan Praktik. Bandung: Nusa Media

Suryana, 2003. Kewirausabaan, Pedoman Praktis Kiat dan Proses Menuju Sukses, Salemba Empat, Bandung 